\title{
Angioid streaks in Jamaican patients with homozygous sickle cell disease
}

\author{
A. M. HAMILTON ${ }^{1}$, F. M. POPE 2 , P. I. CONDON 1 , G. SLAVIN², C. SOWTER ${ }^{2}$, \\ S. FORD ${ }^{1}$, R. J. HAYES ${ }^{3}$, AND G. R. SERJEANT ${ }^{1}$ \\ From the ${ }^{1}$ Medical Research Council Laboratories, University of the West Indies, Kingston, Jamaica; the \\ ${ }^{2}$ Clinical Research Centre, Northwick Park, London; and the ${ }^{3}$ Department of Medical Statistics and \\ Epidemiology, London School of Hygiene and Tropical Medicine
}

SUMMARY Angioid streaks were observed in 21 of 242 patients with homozygous sickle cell disease. Two morphological types were observed. There is no evidence that angioid streaks in Jamaican patients are related to pseudoxanthoma elasticum.

Angioid streaks are a characteristic retinal pattern of pigmented 'fissures' radiating from the disc, lying deep to the retinal vessels and caused by breaks in the elastic lamina of Bruch's membrane. They have been most commonly described in pseudoxanthoma elasticum (PXE), ${ }^{1-6}$ in which they are a logical consequence of the disease process which produces widespread elastic tissue degeneration in skin, arterial walls, gastrointestinal tract, lungs, and eyes. PXE is clinically and genetically heterogeneous, and Pope $^{78}$ has described 2 autosomal dominant and 2 autosomal recessive types. Angioid streaks occurred most commonly in dominant type II and recessive type I groups $(47 \%)$ and were somewhat less common (34\%) in the severe dominant type I group. The very rare autosomal recessive type II variant did not have angioid streaks. They also occur in homozygous sickle cell (SS) disease, ${ }^{9-13}$ but their aetiology in this condition is not understood. The association of SS disease and PXE has occasionally been described, ${ }^{12} 13$ raising the possibility of linkage between the genes for $\mathrm{Hb} \mathrm{S}$ and PXE. It is not clear at present whether the association of angioid streaks and SS disease results from such a genetic linkage or is a direct consequence of the pathophysiology of SS disease. This problem has been explored by clinical and histological examination of the skin and by analysis of haematological indices in patients with and without angioid streaks in SS disease.

\section{Materials and methods}

During the course of prospective studies on sickle cell disease ${ }^{14-18}$ between August 1970 and July 1978

Correspondence to Dr Graham R. Serjeant, Medical Research Council Laboratories, University of the West Indies, Mona, Kingston 7, Jamaica, WI. detailed ophthalmological assessments have been made on 242 patients with SS disease attending the sickle cell clinic at the University Hospital of the West Indies and a group of peripheral sickle cell clinics operated by the staff of the MRC Laboratories. Angioid streaks have been detected in 21 patients (11 male, 10 female), with ages ranging from 30 to 63 years at the time of this study. In 19 out of 21 patients angioid streaks were seen in both eyes, while only the right eye was affected in 2 patients. None of the 21 patients were closely related.

In February 1979, 17 of these patients together with 7 control patients aged 40 years or over with SS disease but without angioid streaks were reviewed by ophthalmological and dermatological examination. Ophthalmological examination included observation by slit-lamp, direct and indirect ophthalmoscopy, and fluorescein angiography.

The skin of the neck and forearms was examined and photographed, and $4 \mathrm{~mm}$ punch biopsies were taken from the right antecubital fossa under local anaesthesia. After fixation in phosphate buffered $10 \%$ formaldehyde, biopsies were mounted and $5 \mu \mathrm{m}$ sections stained for elastin with Verhoef's elastic van Gieson stain. The proportion of elastin in the full dermal thickness was assessed by 2 techniques with a television image analysing system (Magiscan Software, Joyce-Loebl Ltd.). Grey level thresholding was an all-or-none method in which the degree of greyness (black = elastic fibre), allocated a score of 1 or zero, was integrated into a total grey score expressing elastin as a percentage of the dermis. In the tracking method elastic tissue was outlined as a dark image which, after correction of background levels, was expressed as a percentage of dermis.

Haematological comparisons between the 21 patients with angioid streaks and the remaining 221 
Table 1 Clinical informatıon on 17 patients

\begin{tabular}{|c|c|c|c|c|c|c|c|c|c|c|}
\hline \multirow{3}{*}{ Series } & \multirow{3}{*}{$\begin{array}{l}\text { Age } \\
\text { sex }\end{array}$} & \multirow{3}{*}{\multicolumn{2}{|c|}{$\begin{array}{l}\text { Visual acuity } \\
R\end{array}$}} & \multicolumn{5}{|c|}{ Ocular findings } & \multirow{2}{*}{\multicolumn{2}{|c|}{$\begin{array}{l}\text { Skin findings } \\
\text { Elastin scores } \\
(\% \text { dermis })\end{array}$}} \\
\hline & & & & \multirow{2}{*}{$\begin{array}{l}\text { Type of } \\
\text { Angioid } \\
\text { streak }\end{array}$} & \multirow{2}{*}{$\begin{array}{l}\text { Peau } \\
\text { d'orange }\end{array}$} & \multirow{2}{*}{ Peripheral vasculature } & \multirow{2}{*}{ Other findings } & \multirow{2}{*}{$\begin{array}{l}\text { Skin } \\
\text { changes }\end{array}$} & & \\
\hline & & & & & & & & & $\begin{array}{l}\text { Grey } \\
\text { level }\end{array}$ & $\begin{array}{l}\text { Tracking } \\
\text { method }\end{array}$ \\
\hline 1 & $31 \mathrm{M}$ & $6 / 6$ & $6 / 6$ & Type 2 & + & Cap. closure; new vessels & 一 & - & $13 \cdot 3$ & $16 \cdot 5$ \\
\hline 2 & $31 \mathrm{M}$ & $6 / 6$ & $6 / 6$ & 2 & + & Proliferative retinopathy & - & - & $6 \cdot 7$ & $10 \cdot 1$ \\
\hline 3 & $33 \mathbf{F}$ & $6 / 6$ & $6 / 6$ & 1 & + & Cap. closure & - & + & $12 \cdot 9$ & $13 \cdot 9$ \\
\hline 4 & $37 \mathbf{M}$ & $6 / 60$ & $6 / 60$ & 2 & + & Normal & 一 & - & 一 & - \\
\hline 5 & $44 M$ & $3 / 60$ & $6 / 6$ & 2 & + & Cap. closure; new vessels & $\begin{array}{l}\mathbf{R} \text { disciform } \\
\text { degeneration }\end{array}$ & - & $13 \cdot 8$ & $14 \cdot 0$ \\
\hline 6 & $47 \mathrm{M}$ & $6 / 9$ & $6 / 9$ & 1 & - & AV fistula & - & + & $7 \cdot 4$ & $5 \cdot 3$ \\
\hline 7 & $47 \mathrm{~F}$ & HM & $6 / 6$ & 1 & + & Cap. closure & $\mathbf{R}$ vitr. haem. & - & $4 \cdot 5$ & $7 \cdot 0$ \\
\hline 8 & $48 \mathrm{M}$ & $6 / 6$ & $6 / 6$ & 1 & - & Cap. closure & 一 & - & $11 \cdot 6$ & $9 \cdot 4$ \\
\hline 9 & $49 \mathrm{M}$ & $6 / 12$ & $6 / 18$ & 2 & - & Cap. closure & - & - & $6 \cdot 2$ & $9 \cdot 6$ \\
\hline 10 & $49 \mathrm{M}$ & PC & $6 / 6$ & 2 & + & Cap. closure & $\mathbf{R}$ cataract & - & $8 \cdot 1$ & $8 \cdot 8$ \\
\hline 11 & $53 \mathrm{M}$ & $6 / 9$ & $6 / 9$ & 1 & - & Proliferative retinopathy & - & - & $11 \cdot 2$ & $11 \cdot 3$ \\
\hline 12 & $57 \mathrm{M}$ & $6 / 6$ & $6 / 12$ & 1 & - & Normal & - & - & $6 \cdot 6$ & $10 \cdot 3$ \\
\hline 13 & $61 \mathrm{~F}$ & $6 / 12$ & $6 / 9$ & 1 & - & Normal & - & - & $7 \cdot 8$ & $8 \cdot 7$ \\
\hline 14 & $61 \mathrm{~F}$ & $6 / 9$ & $6 / 9$ & 1 & + & Cap. closure; new vessels & - & - & $9 \cdot 8$ & $8 \cdot 1$ \\
\hline 15 & $63 \mathrm{M}$ & $6 / 18$ & $6 / 9$ & 1 & - & AV fistula & - & + & - & - \\
\hline 16 & $63 \mathrm{~F}$ & $6 / 60$ & $6 / 60$ & 2 & + & Cap. closure & Drusen & - & $7 \cdot 8$ & $8 \cdot 9$ \\
\hline 17 & $63 \mathrm{~F}$ & $4 / 24$ & $4 / 24$ & 2 & - & Proliferative retinopathy & $\begin{array}{l}\text { Venous } \\
\text { tortuosity }\end{array}$ & - & 3.7 & $5 \cdot 8$ \\
\hline
\end{tabular}

Table 2 Prevalence of angioid streaks in 242 SS patients based on first ocular examination

\begin{tabular}{|c|c|c|c|c|c|c|}
\hline \multirow[b]{2}{*}{$\begin{array}{l}\text { Age at first } \\
\text { examination } \\
\text { (Years) }\end{array}$} & \multicolumn{2}{|l|}{ Males } & \multicolumn{2}{|l|}{ Females } & \multicolumn{2}{|l|}{ Total } \\
\hline & $\begin{array}{l}\text { No. } \\
\text { examined }\end{array}$ & $\begin{array}{l}\text { No. with } \\
\text { angioid streaks }\end{array}$ & $\begin{array}{l}\text { No. } \\
\text { examined }\end{array}$ & $\begin{array}{l}\text { No. with } \\
\text { angioid streaks }\end{array}$ & $\begin{array}{l}\text { No. } \\
\text { examined }\end{array}$ & $\begin{array}{l}\text { No. with } \\
\text { angioid streaks }\end{array}$ \\
\hline $0-14$ & 9 & $0(0 \%)$ & 13 & $0(0 \%)$ & 22 & $0(0 \%)$ \\
\hline $15-24$ & 43 & $0(0 \%)$ & 49 & $0(0 \%)$ & 92 & $0(0 \%)$ \\
\hline 25-34 & 16 & $2(13 \%)$ & 33 & $2(6 \%)$ & 49 & $4(8 \%)$ \\
\hline $35-44$ & 25 & $3(12 \%)$ & 27 & $0(0 \%)$ & 52 & $3(6 \%)$ \\
\hline $45-$ & 10 & $5(50 \%)$ & 17 & $6(35 \%)$ & 27 & $11(41 \%)$ \\
\hline
\end{tabular}

Note: 3 patients developed angioid streaks at later examinations.

patients were based on mean steady-state values for $\mathrm{Hb} \mathrm{F}$, total $\mathrm{Hb}$, mean corpuscular haemoglobin concentration (MCHC), mean corpuscular volume (MCV), reticulocytes, platelets, irreversibly sickled cell (ISC) counts, and serum iron. The statistical procedures used assumed these indices to be normally distributed, and, as the distributions of $\mathbf{H b ~ F}$, reticulocytes and ISC count were positively skewed,

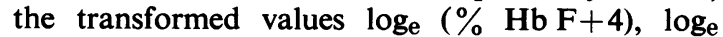
$(\%$ retics +1$)$, and $\log _{e}(\%$ ISC +10$)$ were used to give approximately normal distributions. The constants 4,1 , and 10 added before taking logarithms were chosen to improve the approximation.

Criteria for the diagnosis of SS disease have been described previously ${ }^{19}$ and included electrophoresis under alkaline and acid conditions, quantitation of HB $A_{2}$, and family studies where possible.

\section{Results}

Clinical information, visual acuity, angiographic findings, skin changes, and elastin scores in the 17 patients studied in February 1979 are summarised in Table 1.

\section{PREVALENCE AND AGE OF ONSET}

Angioid streaks had been observed in only 2 of these patients before the age of 30 years, but at older ages the prevalence rose steeply (Table 2), exceeding $40 \%$ 


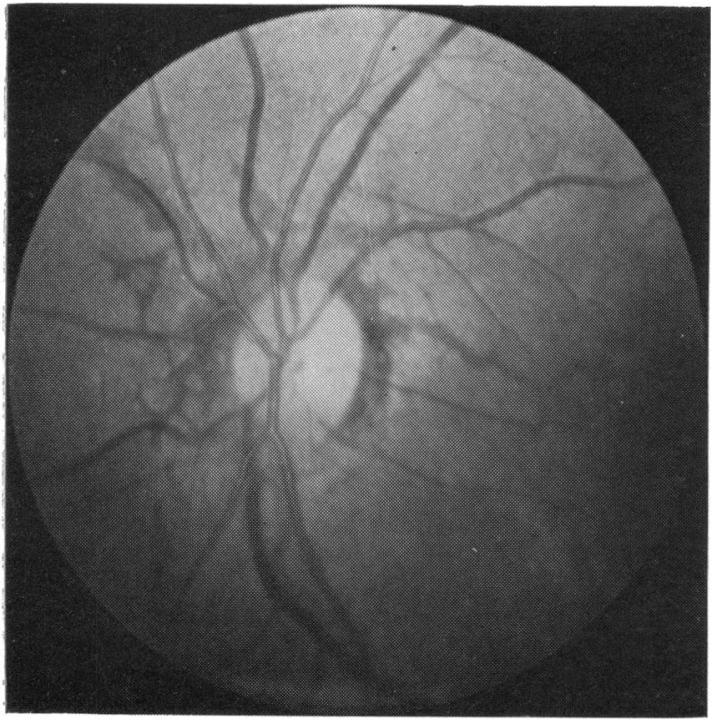

Fig. 1 Black-and-white print of a colour photograph of patient 7 showing angioid streaks as thin dark lines.

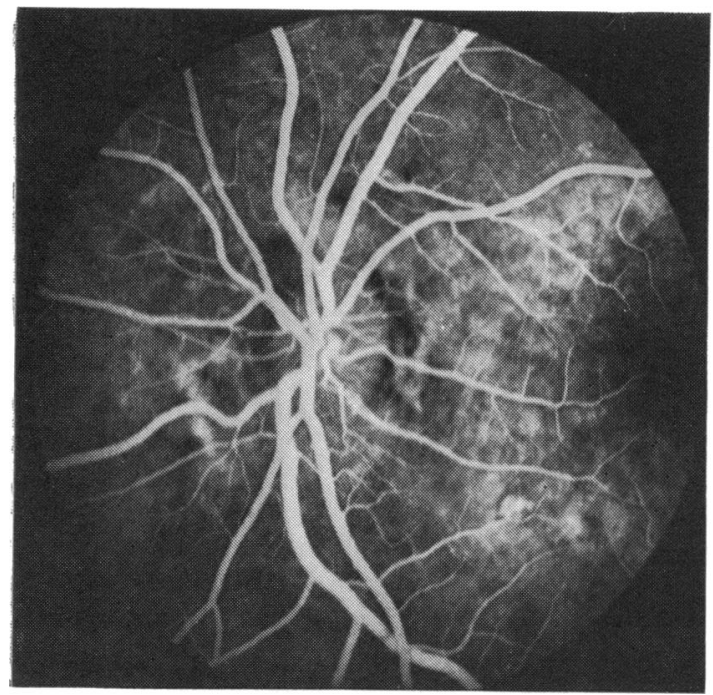

Fig. 3 Fluorescein angiogram of Fig. 1 showing irregular hypo/hyperfluorescence.

in patients over the age of $\mathbf{4 5}$ years. Angioid streaks were slightly more common in males than females, but the difference failed to reach statistical significance, a Mantel-Haenszel test yielding $\chi^{2}=1.44$ (with 1Df).

Age of onset was recorded in only 3 patients in this sample. Angioid streaks developed in a male patient between the ages of 23 and 26 years and in

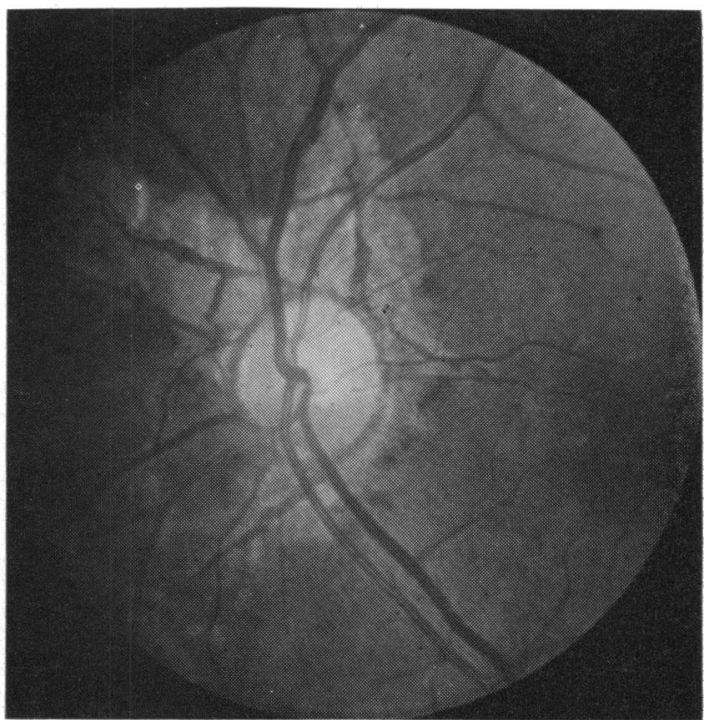

Fig. 2 Black-and-white print of a colour photograph of patient 10 showing thin dark lines with surrounding atrophic areas.

two female patients between the ages of 25 and 31 years and 40 and 44 years. Another female patient had angioid streaks when first examined at the age of 27.

\section{CHARACTERISTICS OF ANGIOID STREAKS}

Two distinct morphological patterns were recognised. In all patients thin black lines radiated a variable distance from the optic disc. In some this was the only finding (designated type 1), whereas in others the thin black lines were surrounded by pale atrophic areas (type 2). These types (Figs. 1 and 2 respectively) showed on angiography irregular hypo- and hyperfluorescence (Figs. 3 and 4).

In one patient (patient 7) with type 1 changes the angioid streaks passed through the macula in both eyes, and in the right eye a vitreous haemorrhage had developed from a previously observed macular haemorrhage. One patient with type 2 changes (patient 5) also had angioid streaks in the macular region, and a large old scar from disciform degeneration was present in the right eye (Fig. 5). Another patient with type 2 changes (patient 16) had irregularly pigmented angioid streaks, thin pigment epithelium, and macular drusen.

OTHER RETINAL CHANGES

A retinal appearance suggestive of peau d'orange was present clinically and confirmed from photographs by independent observers in 9 out of 17 $(53 \%)$ patients. Proliferative retinopathy occurred 


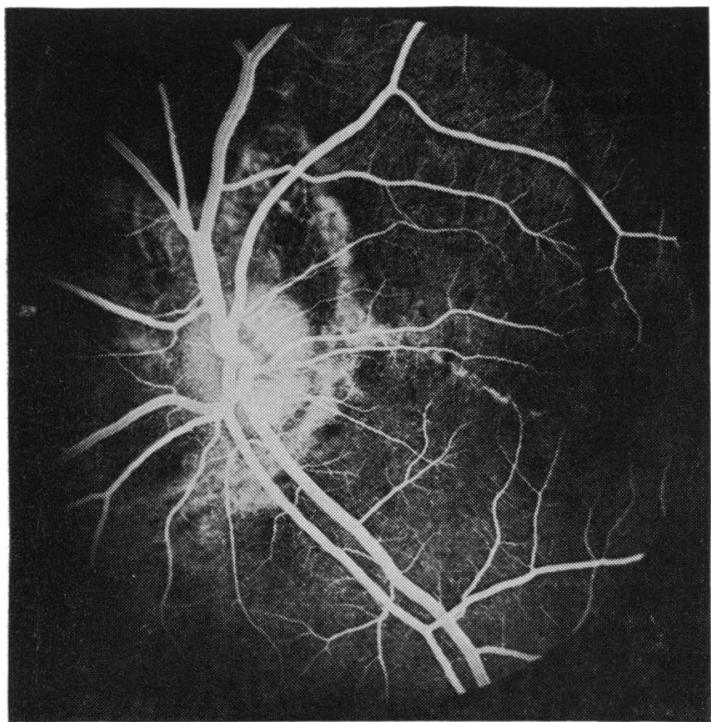

$4 a$

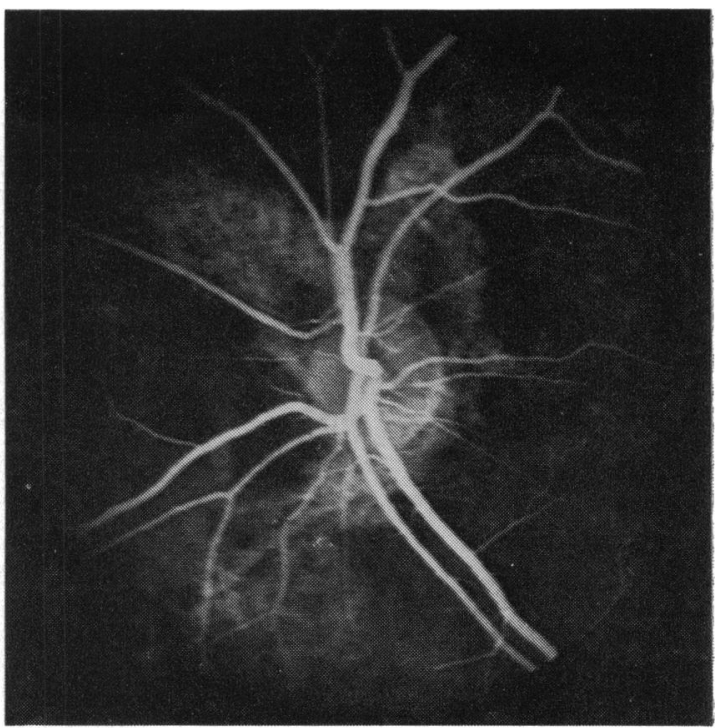

$4 \mathrm{~b}$

Fig. 4 Fluorescein angiogram of Fig. 2 showing (a) in early stages irregular fluorescence, and (b) in the late stages hypofluorescence of the atrophic area.

in 3 of these patients, a similar rate, allowing for age, to that observed in patients without angioid streaks.

DERMATOLOGICAL CHANGES

Three patients showed skin changes suggestive of pseudoxanthoma elasticum with pale yellow papules affecting the neck, axillae, flexures, and abdomen (Fig. 6), but none of these showed the elastic tissue degeneration and calcification characteristic of PXE lesions on skin biopsy. The percentage of dermal elastin in patients with angioid streaks was similar to that observed in 5 SS controls of similar mean age but without angioid streaks (Table 3), and a nonparametric test indicated no significant difference between patients and controls. These observations contrast with the increase in dermal elastin observed in patients with PXE (Pope, unpublished observations).

\section{HAEMATOLOGICAL INDICES}

Means and standard deviations of haematological indices for patients with and without angioid streaks are shown in Tables 4 and 5. The 2 groups were compared initially by Student's $t$ test, which indicated no significant differences between the groups in any of these indices among male patients. In females a lower mean platelet count $(p<0.05)$ was observed in patients with angioid streaks.

As the mean age of patients with angioid streaks was considerably higher than in those without angioid streaks, and as there is some evidence of
Table 3 Dermal elastin scores (\%) by 2 methods compared in angioid streak patients and controls

\begin{tabular}{llcl}
\hline Variable & $\begin{array}{l}\text { Angioid streak } \\
\text { patients } \\
(n=15)\end{array}$ & $\begin{array}{l}\text { Controls } \\
(n=5)\end{array}$ & $\begin{array}{l}\text { Significance of } \\
\text { difference* }\end{array}$ \\
\hline Mean age (years) & 48.9 & $51 \cdot 2$ & - \\
Mean grey level score & 8.8 & 9.8 & NS \\
Mean tracking score & 9.8 & 10.2 & NS \\
\hline
\end{tabular}

"Wilcoxon's signed rank test.

longitudinal changes in haematological indices in SS patients, a more sensitive analysis was performed to allow for possible age effects. Multiple logistic regression analysis ${ }^{20}$ in the 193 patients with steadystate values for all variables indicated that, allowing for age, there was no significant association between angioid streaks and any of the haematological indices taken singly or in combination. In particular the apparent difference in platelet counts in females was no longer statistically significant on making proper allowance for age.

The sample of patients with angioid streaks was small, but graphical procedures failed to suggest any trends that might be established if sample sizes were larger.

\section{Discussion}

A specific association of angioid streaks with SS disease suggested by 23 previously published 


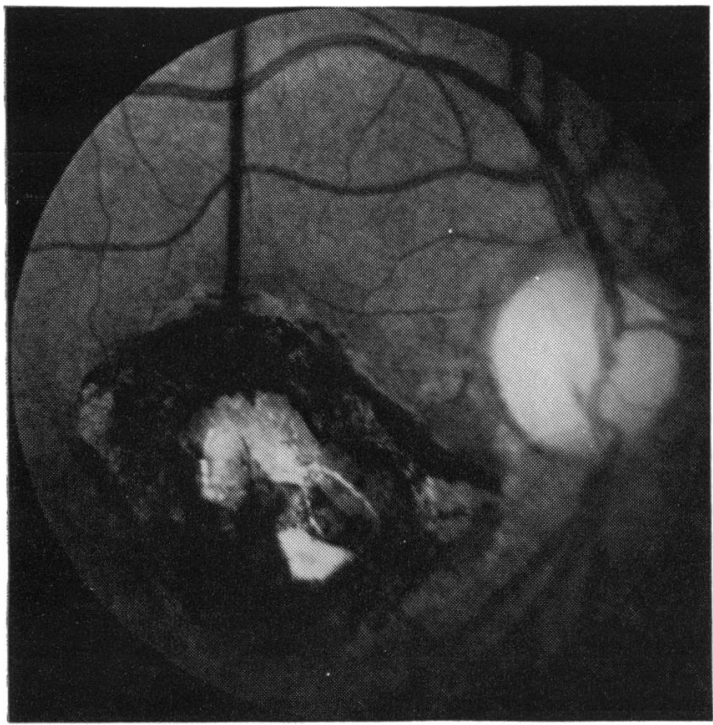

$5 a$

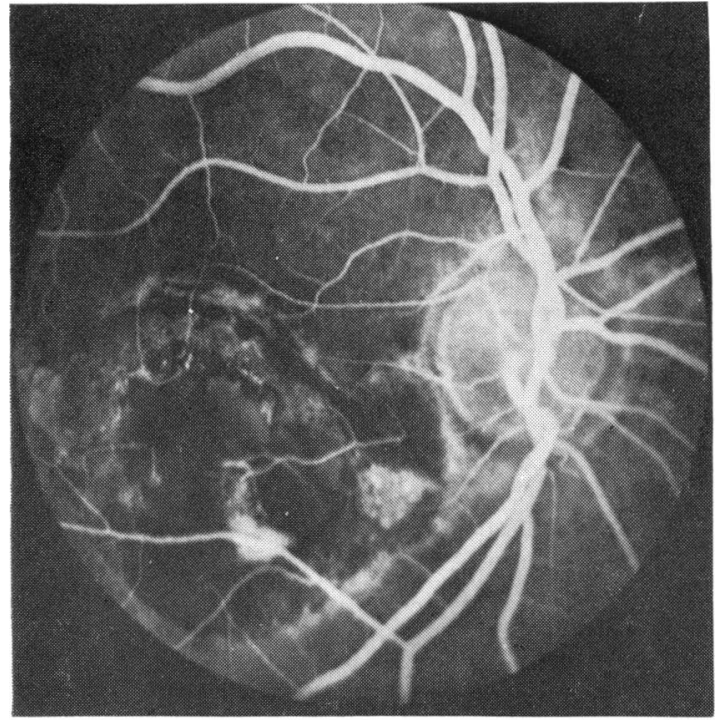

$5 c$

cases ${ }^{5}$ 9-1321 has been confirmed in the present study. Although the age of onset was generally unknown, angioid streaks were seen to develop in both eyes of a male patient between the ages of 23 and 26 years, and in both eyes of 2 female patients between the ages of 25 and 31 years and 40 and 44 years. Although selection for ocular examination was more common among older patients and those thought likely to develop proliferative sickle retinopathy (PSR), there is no evidence of any association between PSR and angioid streaks, and it is felt that

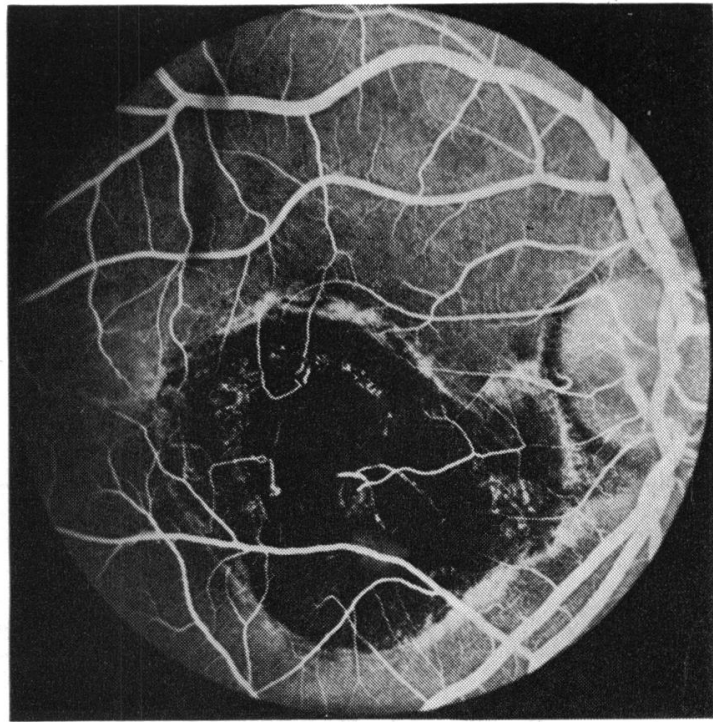

$5 b$

Fig. 5 (a) Black-and-white print of a colour photograph of patient 5 showing large atrophic pigment scar. (b) Fluorescein angiogram in early stages of dye transit showing disciform response in centre of atrophic scar. (c) Fluorescein angiogram in late stages of angiogram showing hyperfluorescence at the site of the residual subretinal vascular tissue.

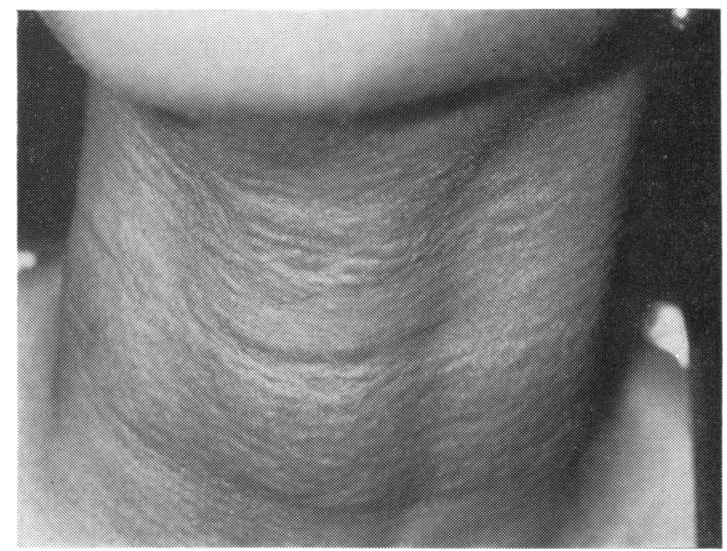

Fig. 6 Black-and-white print of colour photograph showing typical pale yellow papules in neck region. 
Table 4 Comparison of haematological indices in male patients with and without angioid streaks

\begin{tabular}{|c|c|c|c|c|c|c|c|c|}
\hline \multirow{2}{*}{ Variable } & \multicolumn{3}{|c|}{ With angioid streaks } & \multicolumn{3}{|c|}{ Without angioid streaks } & \multirow{2}{*}{$\mathbf{t}$} & \multirow{2}{*}{ Significance } \\
\hline & $n$ & Mean & $S D$ & $n$ & Mean & $S D$ & & \\
\hline Age (years)* & 11 & 44.9 & $9 \cdot 7$ & 92 & $29 \cdot 3$ & $11 \cdot 0$ & - & - \\
\hline $\log _{e}(\% \mathrm{HbF}+4)$ & 11 & $1 \cdot 95^{1}$ & $0 \cdot 31$ & 92 & $2 \cdot 04^{2}$ & 0.33 & -0.91 & NS \\
\hline $\mathrm{Hb}(\mathrm{g} / \mathrm{dl})$ & 11 & 8.09 & 1.06 & 92 & $8 \cdot 33$ & $1 \cdot 38$ & -0.57 & NS \\
\hline MCHC (g/dl) & 11 & $32 \cdot 3$ & $1 \cdot 1$ & 92 & $33 \cdot 1$ & $1 \cdot 7$ & $-1 \cdot 40$ & NS \\
\hline $\operatorname{MCV}(\mathrm{f} 1)$ & 11 & $87 \cdot 9$ & $6 \cdot 5$ & 92 & $88 \cdot 0$ & $7 \cdot 9$ & -0.02 & NS \\
\hline $\log _{e}(\%$ retics +1$)$ & 11 & $2 \cdot 27^{3}$ & $0 \cdot 27$ & 92 & $2 \cdot 33^{4}$ & $0 \cdot 32$ & -0.55 & NS \\
\hline Platelets $\left(\times 10^{\%} / 1\right)$ & 10 & 361 & 87 & 86 & 432 & 147 & $-1 \cdot 51$ & NS \\
\hline $\log _{e}(\%$ ISC + 10) & 11 & $2 \cdot 98^{5}$ & $0 \cdot 30$ & 83 & $2 \cdot 94^{6}$ & $0 \cdot 30$ & 0.40 & NS \\
\hline Serum Fe $(\mu g / d l)$ & 11 & $89 \cdot 7$ & $21 \cdot 8$ & 91 & $97 \cdot 5$ & $25 \cdot 6$ & -0.96 & NS \\
\hline
\end{tabular}

*Age at most recent haematological analysis. NS= not siginificant ( $p>0.05)$

Transformed variables re-expressed as $\%:{ }^{13} \cdot 0 \%,{ }^{23} \cdot 7 \%,{ }^{38} \cdot 7 \%,{ }^{49 \cdot 3} \%,{ }^{59 \cdot 7} \%,{ }^{69.0} \%$.

Table 5 Comparison of haematological indices in female patients with and without angioid streaks

\begin{tabular}{|c|c|c|c|c|c|c|c|c|}
\hline \multirow{2}{*}{ Variable } & \multicolumn{3}{|c|}{ With angioid streaks } & \multicolumn{3}{|c|}{ Without angioid streaks } & \multirow{2}{*}{$\mathbf{t}$} & \multirow{2}{*}{ Significance } \\
\hline & $n$ & Mean & $S D$ & $n$ & Mean & $S D$ & & \\
\hline Age (years)* & 10 & $46 \cdot 9$ & $13 \cdot 7$ & 129 & $30 \cdot 2$ & $12 \cdot 5$ & - & - \\
\hline $\log _{e}(\% \mathrm{HbF}+4)$ & 10 & $2 \cdot 25^{1}$ & $0 \cdot 39$ & 124 & $2 \cdot 23^{2}$ & $0 \cdot 33$ & $0 \cdot 18$ & NS \\
\hline $\mathrm{Hb}(\mathrm{g} / \mathrm{dl})$ & 10 & $7 \cdot 30$ & 0.99 & 124 & 7.92 & 1.05 & -1.80 & NS \\
\hline $\operatorname{MCHC}(\mathrm{g} / \mathrm{dl})$ & 10 & $33 \cdot 2$ & $1 \cdot 0$ & 124 & $32 \cdot 8$ & 1.4 & 0.76 & NS \\
\hline $\operatorname{MCV}(\mathrm{f} 1)$ & 10 & $90 \cdot 2$ & 6.9 & 122 & $89 \cdot 4$ & $7 \cdot 1$ & $0 \cdot 36$ & NS \\
\hline $\log _{e}(\%$ retics +1$)$ & 10 & $2 \cdot 28^{3}$ & $0 \cdot 25$ & 124 & $2 \cdot 31^{4}$ & $0 \cdot 34$ & -0.32 & NS \\
\hline Platelets $\left(\times 10^{\circ} / 1\right)$ & 9 & 348 & 112 & 116 & 452 & 146 & -2.08 & $\mathrm{p}<0.05$ \\
\hline $\log _{e}(\%$ ISC +10$)$ & 10 & $2 \cdot 96^{5}$ & $0 \cdot 18$ & 107 & $2 \cdot 87^{6}$ & $0 \cdot 31$ & 0.87 & NS \\
\hline Serum $\mathrm{Fe}(\mu \mathrm{g} / \mathrm{dl})$ & 10 & $95 \cdot 5$ & $36 \cdot 5$ & 124 & 95.0 & $31 \cdot 7$ & 0.04 & NS \\
\hline
\end{tabular}

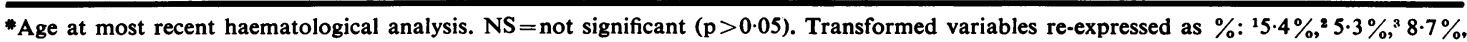
$4.1 \%, 89.3 \%, 87.7 \%$.

observations on age-specific prevalence in this sample should be representative of the clinic population as a whole. In cross-sectional analyses based on the initial ocular examination of each patient angioid streaks were uncommon before the age of 30 years, but the prevalence increased from $7 \%$ in the $25-44$ year age group to $41 \%$ in patients aged 45 years or over. Clearly angioid streaks are an acquired complication of SS disease, which represents a relatively important cause of angioid streaks in some populations.

One possible explanation for this relationship is a linkage of SS disease with PXE, which is an already well established cause of angioid streaks as part of a general process of elastic tissue degeneration. The occasional coincidence of patients with SS disease and PXE $^{1213}$ appeared to support this hypothesis. In the present study, however, although 3 patients showed skin changes compatible with PXE, histological examination and elastic tissue quantitation in skin biopsies has failed to reveal any evidence of PXE, which is in agreement with the observations of Nagpal et al. ${ }^{11}$ It would appear therefore that different mechanisms must be involved in the aetiology of angioid streaks in this population with SS disease.

The increased prevalence of angioid streaks in SS disease compared to that in SC disease (unpublished observations) and the increasing prevalence with age suggest that small vessel occlusion may contribute to the development of angioid streaks. Vascular impairment of the choriocapillaris with resulting damage to Bruch's membrane has been previously suggested as a cause of angioid streaks. ${ }^{22}$ However, the failure of haematological characteristics generally associated with evidence of vessel obstruction (high ISC count and low $\mathrm{Hb} \mathrm{F}$ ) to be significantly commoner in patients with angioid streaks did not support this.

It is possible that angioid streaks are related to abnormalities in iron metabolism. Increased iron staining of Bruch's membrane in angioid streaks was 
noted by Hagedoorn, ${ }^{23}$ and angioid streaks have been observed in 2 patients with haemochromatosis (Jampol, personal communication). In the present study stainable iron could not be demonstrated in biopsies and serum iron levels did not differ between patients with and without angioid streaks. However, this possibility cannot be discounted and requires investigation by histological examination of eyes affected by angioid streaks in SS disease.

The apparent difference in platelet counts in female patients was not unexpected. Cross-sectional data from a previous investigation ${ }^{24}$ indicated a lower mean platelet count in older SS patients, and in the present study patients with angioid streaks were considerably older on average than those without. After allowance was made for age neither platelets nor any other haematological index differed significantly between patients with and without angioid streaks. Certain reservations attend these analyses, since haematological data may have been collected years after the onset of angioid streaks, and there is some evidence of longitudinal changes in haematology. Continuing prospective studies should provide haematological data on patients in the period prior to the onset of angioid streaks and so clarify this situation.

The 2 morphological patterns of angioid streaks have been previously recognised, though their significance is not clear. In a review of 56 patients with angioid streaks of various causes Shields et $\mathrm{al}^{5}$ noted 'light areas coursing along the margins of the angioid streaks' in $32(57 \%)$. Thinning of the retinal pigment epithelium, or a fibrovascular membrane growing through the streak into the space beneath the retinal pigment epithelium, have each been suggested as a cause of this sign. ${ }^{25}$

The prognosis of angioid streaks appears to differ with their morphological appearance. In a study by Shields et $a l,^{5}$ widespread angioid streaks were associated with recurrent haemorrhages and exudative macular changes, whereas mild peripapillary streaks indicated a generally good visual prognosis. Angioid streaks in SS disease tend to be of the latter type, only 2 patients of the present series having macular involvement.

On present knowledge it must be accepted that the aetiology of angioid streaks in SS disease is obscure. There is a need for epidemiological and histological studies of angioid streaks in SS disease to further our knowledge of this complication.

\section{References}

1 Shimizu K. Mottled fundus in association with pseudoxanthoma elasticum. J J Ophthalmol 1961; 5: 1-13.

2 Lawton Smith J, Gass JDM, Justice J Jr. Fluorescein fundus photography of angioid streaks. $\mathrm{Br} \mathrm{J}$ Ophthalmol 1964; 48: 517-21.

3 Rosen E. Fundus in pseudoxanthoma elasticum. Am J Ophthalmol 1968; 66: 236-244.

4 Krill AE, Klien DA, Archer BD. Precursors of angioid streaks. Am J Opthalmol 1973; 76: 875-9.

5 Shields JA, Federman JL, Tomer TL, Annesley WH Jr. Angioid streaks 1. Ophthalmoscope variations and diagnostic problems. Br J Ophthalmol 1975; 59: 257-66.

6 Federman JL, Shields JA, Tomer TL. Angioid streaks. II. Fluorescein angiographic features. Arch Ophthalmol 1975; 93: 951-62.

7 Pope FM. Autosomal dominant pseudoxanthoma elasticum. J Med Genet 1974; 11 : 152-7.

8 Pope FM. The types of autosomal recessive PXE. Arch Dermatol 1974; 110: 209-12.

9 Paton D. Angioid streaks and sickle cell anemia. Arch Ophthalmol 1959; 62: 852-8.

10 Paton D. The relation of Angioid Streaks to Systemic Disease. Springfield: Thomas, 1972; 11-32.

11 Nagpal KC, Asdourian G, Goldbaum M, Apple D, Goldberg MF. Angioid streaks and sickle haemoglobinopathies. Br J Ophthalmol 1976; 60: 31-4.

12 Geeraets WJ, Guerry Du Pont III. Angioid streaks and sickle cell disease. Am J Ophthalmol 1960; 49: 450-70.

13 Suerig KC, Siefert FE. Pseudoxanthoma elasticum and sickle cell anemia. Arch Intern Med 1964; 113: 135-41.

14 Condon PI, Serjeant GR. Ocular findings in homozygous sickle cell anemia in Jamaica. Am J Ophthalmol 1972; 73: $533-43$.

15 Condon PI, Serjeant GR. Ocular findings in hemoglobin SC disease in Jamaica. Am J Ophthalmol 1972; 74: 921-31.

16 Condon PI, Serjeant GR. Ocular findings in sickle cell-B ${ }^{+}$thalassemia in Jamaica. Am J Ophthalmol 1972; 74: 1105-9.

17 Condon PI, Serjeant GR. The progression of sickle cell eye disease in Jamaica. Doc Ophthalmol 1975; 39: 203-10.

18 Condon PI, Serjeant GR. The behaviour of untreated proliferative sickle retinopathy. $\mathrm{Br} J$ Ophthalmol 1980; 64: 404-11.

19 Serjeant GR. The Clinical Features of Sickle Cell Disease. Amsterdam: North Holland, 1974.

20 Nelder JA, Wedderburn RWM. Generalised linear models. $J R$ Statist Soc (A) $1972 ; 135: 370-84$.

21 Condon PI, Serjeant GR. Ocular findings in elderly cases with homozygous sickle cell disease in Jamaica. $\mathrm{Br}$ J Ophthalmol 1976; 60: 361-4.

22 Bonnet P. Les striés angioides de la retina. Arch Ophtalmol (Paris) 1933; 50: 721-50.

23 Hagedoorn A. Angioid streaks. Arch Ophthalmol 1939; 21: 746-74.

24 Emond AM, Holman R, Hayes RJ, Serjeant GR. Priapism and impotence in homozygous sickle cell disease. Arch Intern Med 1980; 140: 1434-7.

25 Gass JDM, Clarkson JG. Angioid streaks and disciform macular detachment in Paget's disease. Am J Ophthalmol 1973; 75: 576-86. 